DIE AFRIKANER:

DEFINISIE EN KONSEP*

\title{
Ter inleiding
}

Die uitnodiging om deel te neem aan hierdie simposium het oot gevolg gehad dat ek deurgaans meer gewonder het oor die vraag waarom die wêreld as't ware so behep geraak het met dic Afrikaner as om ' $n$ antwoord te vind op die vraag wat deur die tema gesuggereer word, naamlik wic is dic Afrikaner eintlik? As volkckundige het ek hicrin iets van die dramatiese ironic ervaar deur te dink aan daardie volke wat so veclvuldig deur ons volkekundiges besoek en waargeneem word, dat dit tot verleen theid en ergerlik. heid lei. In hierdie geval bevind ek my nou in albei rolle te wete dié van etnoloog en van lid van die volk op wie die menigruldige disseksies uitgevoer word.

Watter psigies dwingende misterie omkleef die Afrikanervolk wat hom onweerstaanbaar maak vir die wêreld se belangstelling? Gaan hy gebuk onder 'n treffende laakbaarheid of afwykinge wat die nuusgierigheid gaande maak? Of besit hy 'n bepaalde eienskap wat aan hom 'n beslissingspotensiaal verleen op 'n besondere tyds- en spesifieke ruimtelike knooppunt in die wêreldgeskiedenis? Per slot van sake is die Afrikaner een van die kleiner volke van die wêreld en daarby een van die jongeres. Waar volkekundiges tradisioneel die sogenaamde primitiewe volke tot studicobjek kies, is politieke, ckonomiese en sosialc leiers blykbaar gaande oor wat seker aanvaar kan word as 'n ,ont wikkelde" volk.

Nogtans verwelkom ek die geleentheid om aan hicrdie simposium deel te necm vanweë my algemene belangstelling in dic etnos- of volksverskynsel maar juis ook op grond van besondere geinteres.

* Voordrag by geleentheid van die Somerskool van die Universiteit van Kaapstad, 1 Februarie 1977. 
seerdheid in die bestaan en wese, verlede en toekoms van die Afrikanervolk. 'n Ontleding van hierdie volk, wat die dryfveer daartoe ook al mag wees, bied immers die geleentheid om aandag tc gee aan daardie omstrede fenomeen wat ' $n$ volk genoem word. $\mathrm{Na}$ meer as 'n eeu van sogenaamde etnologiese bedrywigheid moet ons nog skuldig pleit op die klag dat volkekunde beoefen word sonder om aandag aan die volk as sodanig te gee of dan sonder pogings tot ontleding van wat die etnos eintlik is. In die geskiedenis van die vak is dit hoogstens as 'n kapstok gebruik waaraan die bestudeerde kultuur insluitende die sosiale strukture gehang word. Die resultaat was 'n antropologie gebaseer op 'n studie van die kulture van volke sonder om die verskynsel van die kultuurskeppende en -draende entiteite te ondersoek.

Eers in die twintigerjare het enkele etnoloë in hierdie rigting begin werk. Die beweging is egter gefnuik deur die politieke misbruik van die volksbegrip deur die Nasionaal-sosialisme en daarna deur die wêreldwye reaksie wat teen enigiets wat na 'n volk en nasionalisme verwys het, ontstaan het. Vanaf die jare sestig het studente van die politieke wetenskap egter weer op die onvermybare realiteit van die etniese gestuit en hulle ernstige aandag daaraan begin gee.

Om by die Afrikaner uit te kom, sal u my 'n draai by die kwessie van volkskap of etnisiteit moet veroorloof. Daar bestaan selfs op vakwetenskaplike gebied nog veels te veel onduidelikheid en spraakverwarring om sommer met die deur in die huis te val en die agtergrond as iets bekends te veronderstel.

\section{Die etniese fenomeen}

In die program, só verstaan ek dit altans, word 'n leidraad gegee waarvolgens ek die tema behoort aan te pak. Ek vind dit egter onmoontlik om die opdrag uit te voer aan die hand van 'n blote ontleding van die ,huidige kenmerke van 'n tipiese Afrikaner" 
teen die perspektief van die ,grootskaalse omwentelinge wat daar as gevolg van die proses van industrialisasie, verstedeliking en dekolonisasie in Suider-Afrika in die afgelope dekades plaasgevind" het. Deur my streng aan die suggestie te hou, sou die beskouing myns insiens uitloop op 'n ondiepe beskrywing waarin dic tradisionele fout herhaal word naamlik deur'n volk te beskryf uitsluitend in terme van sy' sosiaal-kulturele hede.

Dit sou ook 'n te groot kloof skep tussen die titel en die inhoud. Eersgenoemde veronderstel immers veel meer as wat in die leidraad aangedui word. Sonder om die hele etnogenese van die Afrikaner te teken, moet enkele fasette egter uitgelig en lyne getrek word om die Afrikaner van die afgelope anderhalwe dekade verstaanbaar te maak en enigsins te tipeer.

Soos die geval met haas elke fenomeen van menslike groepering, is die begrip volk nie skerp omlynbaar en geometries bepaalbaar nie. Vrae soos: Wat is 'n volk? Wie behoort tot 'n spesifieke volk? Wat is tipies van die lede van 'n bepaalde volk? is nie met 'n eenvoudige formule te beantwoord nie. Barth (1969) en sy kollegas het hulle reeds ernstig besig gehou met hierdie problematiek. Ander soos Shirokogoroff (1935) en Mühlmann (1938) ${ }^{1}$, baanbrekers op hierdie gebied, het selfs probleme met die term volk ondervind en verkies om, naas die benaming volk, liefs van etnos en selfs van etniese eenhede te praat om sodoende die verskynsel van kleinere eenhede wat nie op die terme volk aanspraak kan maak nic maar tog die kerneienskappe daarvan besit, te akkommodeer.

Hier word slegs 'n paar eienskappe eenvoudig en oorsigtelik opgesom: ' $\mathrm{n}$ volk is as menslike groepering verskillend van 'n ras omdat dit wesentlik 'n oop eenheid is wat kan verander sonder om 'n ander volk te word; deur sy praktiese endogamie is dit andersyds ook geneig om toenemend 'n biologiese eenheid te word;

(1) Vergelyk ook Mühlmann (1964). 
dit is histories-organies in samestelling en streef na eie nasieskap dit wil sê na geopolitiese selfbeskikking. Faktore soos gemeenskaplike geloof, taal, geskiedenis, grondgebied, afkoms ensovoorts is belangrike bindingselemente maar geeneen is ooit absoluut determinerend vir volkskap nie.

In die studie van etnisiteit of die wese van volkskap is daar rondgetas tussen die pole van "der Mensch in der Geschichte" (Bastian, 1860), die onvertaalbare ,psychomental complex" (Shirokogoroff, 1935) en die romantiese idee van Volkstum gepaard met 'n „Volksseele" (Herder, 1785-1791). Elkeen van hierdie begrippe bevat ' $n$ werklikheidselement wat, indien dit organies saamgevoeg word, ons nader bring aan die wesentlike van wat 'n etnos of volk uitmaak. Herder se volksielbegrip wat volgens hom uiting sou vind in die volkstaal en die volkslied, verteenwoordig nog iets van die vereensydigde geykte pogings van antropoloë en etnoloë om net in die kultuur en sosiale strukture die volksbestaan te probeer vasstel. In sy romantiese denke is hy egter op soek na iets minder tasbaars as die gangbare kultuurbegrip.

Bastian (1860) beklemtoon, sonder om in 'n historisme te verval, die historiese faktor in sy breedste betekenis: geneties (beide somaties en psigies), die ervaringe ${ }^{2}$; prosesse van skeiding en vermenging en die inslag van die milieu in die breedste sin van die woord. Geen volk kan sonder 'n geskiedenis wees nie.

Van besondere betekenis is Shirokogoroff (1935) se aksent die etnos as 'n proses wat hy saamvat onder die begrip „psychomental complex". Hierdeur belig hy myns insiens die minder maklik omlynbare maar tog sentrale faktor in die etnogenetiese proses, te wete die selfidentifikasie van mense met 'n bepaalde volk. Shirokogoroff koppel dit met 'n verdere ervaringsveld van die etnos of etniese eenheid naamlik die kwessie van interetniese 
druk. Daarmee bedoel hy die selfbewuswording of verhogende selfbesef ten gevolge van die ervaring van die bestaan van ander volke en die hele spektrum van reaksieverskeidenheid ooreenkomstig die aard van die kontak wat tussen volke plaasvind. Vir 'n begrip van die besondere reaksies van die Afrikaner is hierdie aspek van buitengewone betekenis.

Uit die besondere kompleks van psigiese belewenisse in tyd en ruimte, die totale milieu van geografie, historie, sosiale en ekonomiese, religieuse en politieke bedrywighede, die identifikasie, emosionele eerder as rasionale dinamiek, groei die volkskultuur as ' $n$ veranderende en veranderbare vrug en aanduiding van die bestaan van die besondere volk. Derhalwe is kultuur volksgebonde en identiteitsaanduidend, maar ook tyd-en omstandigheidsgebonde en kan dit nie sinchronies dien as 'n konstante spieël-gestalte van 'n volk nie. Hoe bindend en belangrik taal as een van die kultuurkomponente (Herder, 1785-1791: uiting van die volksiel) ook al vir die bestaan, identifikasie en omlyning van 'n volk is, is die leuse dat die taal heel die volk is, tog ook weer eensydig en oordrewe. Per slot van sake kan verskeie volke dieselfde taal besig en kan een volk se taal 'n verskeidenheid van streekspraak en dialekte huisves.

Hierdie opmerkinge oor die wese van die etniese roep ook enkele aspekte van die metodologie van volkekundige navorsing na vore as 'n tersaaklike aspek van ons tema. Muhlmann (1938) se waarskuwing is eg tersake en sy onderskeiding tussen die intensionele en die funksionele benadering uiters waardevol. Om dit eenvoudig te stel: Die volle waarheid met betrekking tot 'n volk lê selde in die selfbeeld daarvan, maar dit is ewe-eens slegs by hoë uitsondering volkome behels in die "objektiewe" waarneming van buitestaanders. Malinowski (1950) se vereiste naamlik ,to go native" is 'n waardevolle leidraad mits dit nie te absoluut verstaan word nie en geinterpreteer word in Mühlmann (1938) se gedagte van ,begrypende beligting”. Die antwoord op die vraag is ook nie te vind tussen die "subjektiewe" en die "objektiewe" waarneming nie, maar in 'n sinvolle sintese tussen die twee. 
Trouens, ' $\mathrm{n}$ volk se selfbeeld is deel van die realiteit van sy bestaan net soos die vermitologisering van sy geskiedenis en die etnisering van sy religie, maar dit is nie die volle waarheid van sy bestaan nie.

Daar bestaan geen verskil onder skrywers oor die dinamiek, die proses van groei en ontplooiing van 'n volk en sy kultuur nie. Mühlmann (1938) neig weliswaar tot ooraksentuering as hy beweer dat 'n volk eintlik nooit is nie maar steeds word. Tog wys dit op 'n essensiële aspek en dien as korreksie op daardie algemene neiging van binne ' $n$ volk uit om homself en sy kultuur as 'n statiese entiteit te beskou wat geroepe is om alle veranderinge af te wys. Hierdie eienskap staan in die nouste verband met die beklemtoning van eie identiteit. Laasgenoemde veronderstel op sy beurt die wesentlike uniekheid van elke volk wat veelal gesoek word in 'n onveranderlike, meesal vaag omskrewe prototipe of ideaaltipe en wat beskou word as 'n geheel en al onveranderlike.

Herder (1785-1791) het te midde van sy poëties-filosofiese en romantiese aantekeninge oor die „Volkstum” die spanning met betrekking tot die unieke van die etniese entiteit en die universele van die mensdom goed raakgevat met sy waarneming van die konflik tussen „Volkstum und Zivilisation”. Eersgenoemde verteenwoordig die unieke van elke volksidentiteit; wat na sy mening hoofsaaklik uitdrukking vind in die volkslied en in die volkstaal. Beskawing is daarenteen 'n nivellerende mag, 'n ,,antiunieke" identiteitsbedreiger. 'n Volk wat sonder weerstand en seleksie slegs oorneem, loop gevaar om sy identiteit prys te gee. 'n Volk wat alle beskawingsinvloede afwys, word egter bedreig deur verstarring en ondergang.

Die ingeboue dinamiek in die lewe van 'n volk moet in verband gesien word met voortgaande ontplooing deur beheersende aanpassing by sy milieu. Die roeping tot kultuurbou en -bewaring word beleef en gehoorsaam deur individue maar dan binne die ommuring van hulle respektiewe volke - weliswaar nie in volle- 
dige afgeslotenheid nie maar in onderlinge kontak, allereers tussen individue binne dieselfde volk maar ook tussen lede van verskillende volke. Solank ' $n$ volk bestaan, is hy wordend - hetsy negatief of positief.

'n Belangrike rol word in die volksdinamiek toegeken aan twee teenoor mekaar staande prosesse, te wete dié van fissic en fusie (Fortes, 1950), van middelpuntsoekende en middelpuntvliedende magte, van integrasie en van skismogenese (Mühlmann, 1938). Elke volk is tot op groot hoogte die historiese produk van albei hierdie prosesse en elke volk is gedurig onderhewig aan die werking daarvan. Uiteraard wissel die intensiteit daarvan volgens ek. sterne sowel as interne omstandighede. Dit kom my voor of die aktiwiteit van die prosesse 'n bepaalde verband hou met die in tensiteit en aard van die interetniese druk. Hoe hoër sodanige druk, des te meer word sekere skismogenetiese aspekte wat in enge relevansie verkeer met die bepaalde situasie, uitgespel. Maar gelyktydig word die integrerende of fusie-meganisme, by wyse van spreke, sterker geaktiveer ten einde 'n behoudende ewewig te bewaar.

Ek het reeds melding gemaak van die neiging om vir die volksmens en vir die volkskultuur 'n prototipe op te stel. Vergelyk maar die sogenaamde etniese grappe wat 'n voorbeeld is van die prototipe of dan van die tipiese soos ander dit waarneem of liewer, vir hulle voorstel. Dit verteenwoordig die verskynsel van stereotipering. Van binne uit is die prototipe meesal sterk heroies - een van die relatiewe begrippe wat enigiets kan beteken omdat dit saamhang met die waardesisteem van die betrokke volk: die Engelse gentleman, die Pruisiese militaris, die hartstogtelike Italianer, die stoere Afrikanerboer, die suksesvolle Amerikaanse demokraat. Daarom is die selfbeeld van 'n volk belangrik as intensionele werklikheid, maar ewe misleidend as 'n getroue weergawe van wat die volk werklik is (Mühlmann, 1938). Per slot van sake verteenwoordig dit wat die volk graag wil wees, dit wat hy ag as wat behoort te wees en nie noodwendig wat hy is nie. 
Intensioneel speel die prototipe dus 'n belangrike rol in die volksbestaan naamlik as 'n nav'olgenswaardige voorbeeld en maatstaf. Die verskil tussen wat behoort te wees en wat werklik is, kan so ooglopend word dat veral die jeug by geleentheid daarteen in opstand kom omdat hulle die diskrepansie ervaar as skynheiligheid: om dan maar weer ' $n$ ander prototipe daar te stel wat in die loop van tyd ewe werklikheidsvreemd mag word.

Funksioneel of „objektief" beskou, lewer die prototipe of ideaaltipe baie probleme. Basies is die beeld ' $n$ verpersoonliking van die besondere en nie van die algemene nie. Daarby word dit verweer deur veranderende omstandighede. Die tipes hierbo genoem, was enigsins denkbaar onder omstandighede van die vorige eeu, maar demokratisering, verstedeliking, ryksverval en dergelike meer maak dit nie meer houdbaar nie.

Verder word die problematiek geopenbaar in die neiging om erflik genetiese aspekte en die invloed daarvan op die gestalte van die volkslewe te verwar met milieu-bepaalde lewensvorme en uitdrukkinge van die volkswese. So is die Afrikaner dikwels geteken as van nature gasvry, in besit van 'n besondere humorsin, streng godsdienstig en so meer ${ }^{3}$ ). Ek kan moeilik aanvaar dat hierdie eienskappe geneties verkry is. Dit was hoofsaaklik uitvloeisels van sy landelike lewenswyse wat erg verskraal is deur verhuising na die stad.

In stede van 'n starre prototipe van ' $\mathrm{n}$ volk te veronderstel, moet rekening gehou word met die werklikheid van verskeidenheid in eenheid. ' $n$ Volk is per slot van rekening 'n kompleksiteit ${ }^{4}$ ). (Mühlmann, 1938). Selfs die vraag na die ,tipiese" Afrikaner is wetenskaplik 'n dwaling. Die eenheid van 'n volk lê allereers begrepe in die selfidentifikasie van die lede daarvan met hulle

(3) Vergelyk o.a. Bosman (1945).

(4) Vergelyk veral sy drie „Vlakke” van kennis van die etniese. 
bepaalde volk en deels in die algemene patroon ran die rolkskultuur waarin die gemeenskaplıke taal 'n oorheersende rol specl. Maar binne die volk self bestaan 'n diversiteit volgens woonplek, generasies, geloot, beroepe, klasse, ensoroorts.

Die Afrikaner het ondanks die geloof dat dit 'n monolitiese eenheld is, deur die loop van sy geskiedenis sy trekkers en sy tusblyers gehad; sy voorlopers en sy agternakommers; sy avonturiers en bestendiges; sy jukskeibrekers en sy kontormiste; sy hensoppers en sy bittereinders; sy lafaards en sy helde; sy verligtes en verkramptes; sy Doppers en Filistyne; Afrikaners met Engelse harte en Afrikanerharte (selfs enkeles met Hollandse en Duitse en Franse harte).

In hıerdie uitdrukking van die GKA word op baie korrekte wịse die vraagstuk van die volksgrense en daarmee saam dic van die personeel van 'n volk geraak. Lidmaatskap van 'n volk, veral van 'n enigsins ontwikkelde volk, word nie determınisties bepaal deur totale gemeenskaplikeheid van polıtieke oortuiging en godsdienstige geloof, soortgelykheid van beroep of sedelike maatstaf, eendersheid van smaak of aanleg of temperament nie. Dic grootste decl van $n$ volk se lede bekom lidmaatskap deur geboorte maar „vreemdelinge" kan deel word deur te aanvaar en deur aanvaar te word. Hierdie verskynsels bevat 'n waarskuwing teen veralgemenıng oor 'n volk sowel as teen die indwing in 'n keurslyf. Ek meen dat dit 'n gebrek is in prof. Kruger (1976) se artikel oor die $\lambda$ frikaner. Sy reaksie is sterk gekant teen 'n neiging wat in enige volk aangetref word veral wanneer dit hom bedreig voel in sy bestaan en toekoms, om individue wat te ver van die min of meer gemeenskaplike norm of van die ideaal-tipe afwyk, met wantroue te betrag en selfs as verraaiers te beskou. Uiteraard kan dié optrede ,verkeerd" wees. Tog moet dit onderken word as 'n verskynsel wat opstu uit die volk en gemik is op beveiliging en identitcitsbehoud en as 'n proses steeds aktief is. Dit is deel van die fusiemeganisme.

Dıe feit bly egter dat volkskap daarmee nie ontsê kan word in die 154 
wetenskaplike sin van die woord nie al word die wyse waarop 'n persoon sy volkskap beleef ook gekritiseer. Om die stelling te illustreer word verwys na omstrede persoonlikhede wat, hoeseer hulle ook al verskil het of nog verskil, almal Afrikaners was of is: Smuts en Hertzog, De Wet en Botha, Bram Fischer en H.F. Verwoerd, Breytenbach en Van Wyk Louw, Beyers Naude en Koot Vorster. Onderlinge persoonlike bejeëning het met die feit van Afrikanerskap niks te doen nie.

\section{De Atrikaner vandag}

Die wydlopige en omslagtige agtergrond moet ons nou bring by 'n blık op die Afrikaner van die afgelope dekade en 'n half. Maar voordat dit met vrug gedoen kan word, moet tog nog in rekening gebring word dat die Afrikaner sedert 1960 nie begryp en/of beskryf kan word sonder kennis en begrip van sy wordingsproses voor die tyd nie. Oor die Afrikaanse etnogenese van die voorgaande drie eeue kan ek nie hier breedvoerig handel nie (vergelyk Coetzee, 1977). U moet my egter veroorloof om enkele verklarende opmerkıngs daaroor te maak.

1. Die Afrikanervolk het basies oor 'n tydperk van anderhalwe eeu gegroei uit brokstukke oorwegend van die Nederlandse, Franse en Duitse volke met geringe bymengsels van ander Luropese en nie-Europese volke wat hulle in Suid-Afrika na 1652 gevestig het.

2. Die nuwe volk het van die begin van sy ontstaan af die aanwesigheid van die inheemse volke beleef as ' $n$ vorm van interetniese druk waarin getalle saam met beskawings- en geloofsverskille steeds ' $n$ bedreigende rol ten opsigte van die fisieke voortbestaan, die beskawingspeil en die etniese identiteit gespeel het.

3. Die interetniese druk is sedert die einde van die 18 de eeu versterk en gekomplıseer deur die koms van 'n ander Europese etniese komponent, nie as gelyke nie maar as oorheerser wat sy kultuur en politieke mag boweskikkend tot die van die Afrikaner ge- 
maak het. Die vasgedruk wees van die Afrikaner tussen Brit en Bantoe is konstant oor die loop van anderhalwe ecu volgehou. 4. Dit word as 'n esenaardigheid van die Afrikaner beskou dat hy hom gedistansieer het van die Nie-Blankerolke wat cuniese aanvaarding betref. Afgesien daarvan dat ander Blankes in SuidAfrika oor die algemeen nie anders opgetree het nie, is die kenmerk nie onbegryplik nie gesıen die beskawingsverskille en gewaardeer teen die verskil in getalsverhoudinge.

5. Afstand in tyd en ruimte het die nuwe volk van turopese herkoms mettertyd steeds losser gemaak van sy oorspronklike moedervolk (proses van tissie) en veel meer so as in die geval van enige ander Europese of ander koloniste in Suid-Afrika en elders op die kontinent. In die naam wat geleidelik aanvaar is as rolksnaam, word uitdrukking gegee aan die afsonderlıke volksidentiteit wat tot stand gekom het en die assosiasie met 'n nuwe gebied as patria.

6. Die blootstelling aan voortdurende en intense interetniese druk het diep merke op die Afrikaner se volksgedrag nagelaat. Veral drie aspekte van sy lewe is daardeur geraak: liggaamlike voortbestaan en behoud van lewensmiddele; taal as besondere kulturele komponent en uitdrukking van die volksıdentiteit en in meer onregstreekse vorm ook dic godsdienstıge en sedclike grondslae van sy kultuurpatroon. Boweal is hy herhaaldelik in sy strewe na eie nasieskap bestry. Die wortels van die geslotenhcid of beweerde "laagermentaliteit" van die Afrikaner moet veral in hicrdie faset van sy geskıedenis gesoek word. Dit is opmerklik dat in tye van verslapping van die druk soos in die Republick van die Oranje-Vrystaat en gedurende $n$ korter tydperk in dic ZAR se bestaan, die geslotenheid minder strak geword het.

Die uitwendige gestalte van die Afrıkaner van ná 1960 is verskillend van dié van 1860; die Afrikaner van 2060 sal op sy beurt 'n ander uiterlike beeld vertoon as sy huidige voorganger. (ictalletoename, milieu-belewenis, politieke, ekonomiese en sosialc omstandighede, speel 'n bepalende rol in die ontplooingsproscs. n Lewende, dinamies groeiende volk ondergaan voortdurend $n$ toc- 
nemende diversif gepaard met in sterker onderliggende integrasie.

Selfs oor $\mathrm{n}$ betreklık kort tydperk van drie dekades is die verskil merkbaar in die lewe van die Atrikaner. 1 ot ongeveer 1960 is sy lewe grootliks beinvloed en gevorm deur die interetniese druk: enersyds van die kant van die Britse politieke, ekonomiese en kulturele mag; andersyds het die skaduwee van die ,Swart gevaar" in in die vorm van getalleverhoudinge, beskawingspeil en historiese assosiasies oor hom geval.

Die ekonomiese laagtepunt van die Armblanke-vraagstuk was nouliks agter die rug teen 1960. Die Boer het ondertussen stedeling geword. In 1948 het die Republikeinse Afrikaners die politieke mag herower en hulle eerste dekade benut met die oprigting van 'n barrikade van beskermende apartheidsmaatreëls in die vorm van uitgebreide wetgewing.

$\mathrm{Na}$ 'n aansienlike lang tydperk in sy geskiedenis het die gesamentlike Afrikanervolk in Suid-Afrika as volk weer in die ruimte gestaan. Wat in 1948 begin is, is in 1961 afgerond deur die uitroep van die Republiek en tot baie se verligting selfs die verbreking van die band met die (Britse) Statebond. Armoede is deur welvaart vervang; onderhorigheid deur magsbeheer. Bowendien was die sestigerjare die begin van 'n belangrike waterskeiding tussen die generasies. Van die geslag van die ,eeu van onreg”, die Tweede Vryheidsoorlog, die konsentrasiekampe en die vernedering van die Vrede van Vereeniging beleef het, was weinig nog in die lewe. Die kinders van die Tweede Wêreldoorlog en van (26 Mei) 1948 het reeds stemreg geniet. Hulle verste gesigseinder na die kant van die verlede was 1939 tot 1946 en nie 1899-1902 of 1910 nie. Dit was 'n geslag met 'n totaal ander beleefde verlede as dié van hulle ouers.

Dit moet as 'n onbetwisbare feit erken word dat in die vervulling van die hoop en begeerte van die ouere volkslede en deur die onbekendheid met die verlede van twee generasies vroeër, 'n gevoel 
van verligting deur die Afrikaner gehuiwer het. Die interetniese druk is ,afgewend"; die Afrikaner het die politieke mag uit die hande van die Engelse verower ${ }^{5}$ ) ; hy is besig om met sy beleid en wetgewing die gevaar van oorheersing deur die Swartes 'af te weer'. Ekonomies gaan dit goed en haal die Afrikaner sy agterstand in. 'n Nasionale Party-regering in die Republiek van Suid-Afrika is emosioneel aanvaar as ' $n$ waarborg van veiligheid, 'n effektiewe bastion teen alle bedreiging en 'n bereiking van alle ideale. Met die politieke mag in sy' hande, sou hy hom. self vorentoe beveilig. Dit altans, was die gevoel van die meerderheid van Afrikaners. En gevoel is 'n uiters belangrike faktor en $\mathrm{krag}$ in ' $\mathrm{n}$ volk se lewe en optrede - veel belangriker as die rede.

Vandag kan ons met minder emosic en in die lig van die ervaring grootliks anders daaroor oordeel. Trouens, tóé reeds het stemme teen oorgerustheid en utopiese verwagtinge opgestaan. Só besig was die Afrikaner vroeër in sy onderhorige toestand met Brittanje en die Swart Afrikane in sy onmiddellike omge wing dat vir alle praktiese doeleindes die hele wêreld vir hom net hieruit bestaan het. Nou was hierdie wêreld, vir'sy gevoel verslaan. Die oplaaiende haat en afkeer en kritiek van die wêreld via die VVO is afgemaak as lawaaierige praatjies, onbe gryplike vooroordeel en geykte haat teen die Afrikaner. In clk geval sou dit kom van mense wat geen begrip van Suid-Afrika het nie en wat liewer eers voor hulle eie deure behoort te vee. Dic OAE is gewaardeer as blote werktuig van dic kommunisme (aan die meerderheid eintlik ewe onbekend in sy ideologic en strategie as die Nasionaal-sosialisme waarvan die O.B.-Afrikaners beskuldig is) en daarby ' $n$ uiting van dic politieke onvolwassenheid en hebsug van die Swart Afrikane. Derhalwe is aan die wêreld-afkeer en aan die geslote deure van Afrika nic veel beteken is geheg nie.

Dic atmosfeer van verligting of bevryding het politieke en sosiale

(5) Dit was die algemene opvat ting van die 'nasionale' Afrih aners. 
kritick gestimulcer. Weliswaar was die stcmme van politieke leiers, koerante en kultuuroormanne teen die jaar 1965 nog sterk en hard teen enige skynbare afwyking van die tradisioncle. Maar die omstandighede was teen die handhawers van blote tradisionalisme. Nòg die invloed van dr. Verwoerd nòg van enige liggaam kon roorkom dat nonkonformisme kop uitsteek en selfs toeneem. Wanhopige ,verkrampte aanslae" 6 ) het misluk selfs ten koste van politieke eenheid waarna naarstigtelik gesoek is. 'n Stryd het ontbrand tussen verlig en verkramp, tussen progressie en tradisionalisme. Etnologies gesien, het ons die interessante verskynsel beleef van nativistiese bewegings wat die volk se toekoms wou vergestalt in die goue verlede.

Die verandering van premier teen die helfte van die sestigerjare, hoe tragies en betreurenswaardig die daad wat dit veroorsaak het, ook al was en die gevolglike verskil in persoonlikheid tussen die heengegane en die nuwe bekleër van die gesagsposisie, het myns insiens die bevrydingsbesef by die jonger generasie bevorder en meteens ook die weerstand teen verandering by die behoudendes versterk. So 'n proses van aksie en reaksie is oorbekend onder soortgelyke omstandighede. Die uitwaartse beleid het begin eers in denke, belangstelling en kennisname, daarna in politieke beleid en diplomasie. Meer as Britte en „Kaffers” het Afrikaners se aandag in beslag begin neem: die VSA, die res van Wes-Europa (met Brittanje en Nederland relatief toenemend op die agtergrond); die volke en nasies en regerings van Afrika vanaf die Limpopo tot aan die Middellandse See; nadere kennismaking met die kommunisme in Russicse en Sjinese restalte.

Dic opkoms van die Afrikaanse sake- en beroepsman moet hierin ook nie uit die oog verloor word nie. Die Reddingsdaadbond het in 'n gunstige ekonomiese klimaat sy vrugte begin afwerp. Afrikanersakelui moes met die internasionale ekonomiese wêreld saamleef en moes vir die doel nie net die politieke tendense waar-

(6) In Serfontein (1970) word 'n ekstremistiese weergawe hiervan gegee. 
voor daardie sektor erg gevoelig is, dophou en walardecr nic matr moes in kontak en onderhandeling met buitelandse en internasionale finansiers en nyweraars Suid-Afrika, dit wil sê die Afrikanerregering, se doen en optrede verklaar en regverdig.

Van Engelstalige kant is hierdie groot openheid graag beskiy f en voorgestel as 'n teken dat die Afrikaner nou besig is om ontslae te raak van sy „laager-mentaliteit". Dit is onder andere een van die eienskappe wat neerhalend van buite aan die Afrikaner toegedig is enersyds sonder werklike begrip daarvan, tweedens uit on begrip dat elke volk onder noodtoestande saamsluit rondom 'n tradisionele simbool en ten slotte sonder om raak te sien hoe Engelstaliges, Kleurlinge en Swartes in Suid-Afrika op dieselfde wyse reageer. By Afrikaners het dic indruk, nie ten onregte nie, posgevat dat solank hulle nie Engelse politieke en kulturele waardes wil aanvaar en toevlug in die "Castle" gaan soek nie, hulle beskuldig word van 'n outydse, uitgediende en eksklusiewe laermentaliteit.

Vir sover as wat die verskynsel van geslote poorte egter toepaslik is en die werklikheid weerspieël, is dit maar één moontlike reaksiewyse wat onder spesifieke omstandighede te voorskyn kom. Per slot van sake word dieselfde Afrikaner as 'n uiterste individualis beskryf. Dic volle waarheid is dat Afrikaners, ook gedurende die sestiger- en sewentigerjare, soos cnige ander volk onder die skaduwee van 'n bedreigde interetniese druk sy gcledere sluit maar nadat die bedreiging afgeweer is, weer elkeen op cic bene staan. Dit is wat ook gedurende dic afgelope dekade gebeur het. Binnelands was die toestande in elk geval sodanig dat die Afrikaner hom minder bedreig gevoel het.

Die voorgaande moet die waarnemer egter ook nie mislei tot dic valse konklusie van 'n absoluut geslote, onverstoorbare, monolitiese Afrikanereenheid in politieke, kulturele en godsdienstige sin nie. Elkeen weet dat sedert 1912, om nie cers terug te gaan tot die dae van Potgieter en Retief, Paul Kruger en Piet Joubert nie, die Afrikaners polities voortdurend in twee of meer kampe ver- 
keer het. Lers was dit Nat en Sap. Daarna Smelter en Gesuiwerde; gedurende die corlogsjare V.P., Nasionale Party en OssewaBrandwalg. Hicrdic rerskille is tewecggebring deur 'n kompleks van oorsake: lojaliteit aan leiers, verskil in politicke siening, blote rerskil in politicke tradisie en metode, ensovoorts. Dit behoort bekend te wees dat menige Sap eintlik vir Louis Botha en Jan Smuts gevolg het met die oortuiging dat hulle besig is om dic Engelse te uitoorlé en cventueel die Republick sal herstel. Anders as wat dikwels gedink en beweer is, was alle Sappe nic Alrikancrs met Engelse harte nie maar baic was roorbeclde van Afrikanerpatriotte in murg en been, onverbeterlike handhawers van Afrikaans as rolkstaal en van Afrikanertradisies. Daar was selfs dicgene wat Sappe gebly het omdat dit hulle oortuiging was dat die Britse oorwinning in 1902 'n Godsbeskikking was waarteen hulle hulle nie mag besondig deur verset nie. Dit word miskien ook nie altyd besef nic dat hoeseer die grootste deel van die Afrikaners algaande op politieke vlak van Botha en Smuts verskil het, ecrsgenoemde uit piëteit sy opstal wat deur die Britse magte afgebrand is as ' $n$ monument bewaar het. Smuts het die sobere Afrikaner in sy lewenswyse gebly tot die dag van sy dood.

Dit is waarskynlik minder bekend dat die beswaar van baie Transvaalse Sappe teen die Nasionale Party bestaan het in dic beskuldiging dat eertydsc hensoppers en National Scouts en hulle kinders Hertzog-ondersteuners geword het!

Teen die veertigerjare het ek ook nog menige vurige Nasionalis in Kaapland aangetref wat graag Engels gepraat en as skryftaal gebesig het. Dat Afrikaners in toenemende mate 'n Engelse grondpatroon in hullc algemene lewenswyse en kultuur aanvaar en geinkorporecr het en steeds vreemder staan teenoor hulle Dictsc bakcrmat, is geen fantasie of geheim nie. Toenemende persoonlike of onregstreekse kontak met die Anglo-Amerikaanse kultuur bly nic sonder invloed op die Afrikaanse kultuurpatroon nic, sonder dat dit noodwendig die Afrikaner se volkslojaliteit benadecl. Hier beleef ons Herder (1785-1791) se problematiek van die spanning tussen volkskap en beskawing. 
Ten opsigte van die Afrikaner van die afgelope anderhalwe dckade, het die Engelstalige media vir sover as wat dit as spreekbuise van die Engelssprekende en -lesende Suid-Afrikaners, Blank, Bruin en Swart aanvaar kan word, 'n verdere oordeelsfout begaan. Die populêre beeld is geskep, naamlik dié van geharde tradisionaliste vanweë hulle gereformeerde of Calvinistiese geloof. Derhalwe word enige „progressiewe" optrede of uitsprake van daardie kant as verbasend en selfs as sensasioneel beskou. Dit is waar dat veel in die Afrikaner se tradisies terug te voer is tot sy Calvinistiese erfenis. Maar die feit word ook weer oordryf en veelal gebrekkig geinterpreteer (Coetzee, 1969).

Eintlik het ons die posisie bereik dat Calvinisme aan die een kant as 'n Afrikanerdeug maar andersyds ook weer as 'n -ondeug aangedui word. Alle Afrikaners, en nog minder alle konserwatistiese en ,verkrampte" Afrikaners, is nie noodwendig Calviniste nie. Wat dit betref, kan die huidige geslag Afrikaners in drie kategorieë verdeel word. Die eerste groep is feitlik totaal gespeen van en onbekend met die grondslae en beginsels van die Calvinisme. ' $n$ Tweede kategorie bestaan uit Afrikaners wat nog sweer by 'n Calvinistiese tradisie maar by wie kennis en juiste skriftuurlike interpretasie van erkende Calvinistiese beginsels reeds grootliks ontbreek wanneer hulle te staan kom voor uitdagings van die moderne wêreld. Myns insiens bestaan die derde groep uit die minderheid. Dit is diegene wat nog 'n streng trou en opregte oortuiging ten opsigte van die Calvinistiese lewens- en wêreldbeskouing handhaaf al is hulle nie noodwendig altyd in staat om dit te vertolk in terme van die hedendaagse problematiek nie. Ek meen dat werklike konserwatisme of verkramptheid eerder 'n kenmerk van die tweede kategorie is omdat Calvinisme vir hulle 'n blote kulturele kors geword het sonder prinsipiële inhoud en verantwoording.

Oor andere se siening van die Afrikaner wil ek verder nie uitwei nie ${ }^{7)}$. Allereers kan ek my moeilik aanmatig om 'n onbevoor-

(7) Vergelyk oor Van der Merwe (1975) J.H. Coetzee se resensie in Woord en Daad. Julie 1976.

162 


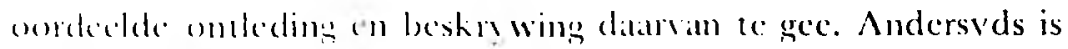
daanow receds breed gehandel in in rorige byeenkoms van hicrdic atided en hall die cerstehandse menings van lingelstaliges, Kleurlinge. Indiers. Swart leiers en ran buitelanders volledig gelees word in die betrokte rerslag. lik wil my egter verstout om te beweer dat ek nie baie beindruk was met die wetenskaplike gehalte an al die roordragte nic. Matar al sou die meningsuitings nic 'n hoë mate valn waturheid bevalt nie, moet die emosionele en veralgemeende alard dairvan nogtans as werklikheid waargeneem en gectalueer word net soos die kommunistiese leuenpropaganda omwar is maar 'n gevalarlike en betekenisvolle werklikheid uitmaak wat nie sonder gevalar geignoreer kan word nic.

Die relevante en sinvolle vir ons is dat baic Afrikaners in die afgelope anderhalwe dekade ook 'n houdingsterandering met betrekking tot die lede van ander berolkingsgroepe ondergaan het. Dic verandering loop ook langs twee bane. ,Vcrliberalisecrde" Alrikaners toon die neiging om onder invloed van die nuwere teologiese en filosofiese strominge of los datarvan dic aksent geheel en al te verskuif tot dic persoonlike verhoudinge met loslating ran die volksaspek. Teenoor hulle staan die uiterste handhawers van volksidentiteit wat, as dit moontlik was, selfs enige kontak met nie-Afrikaners sou wou vermy. 'n Derde kategorie is diegene wat juis met 'n berocp op die Skrifgesag 'n sintese wil teweegbring tussen dic bestaan en handhawing van volksidentiteit en dic persoonlike bewoënheid oor die lot van ander volke en hulle lede tesame met die belewing van dic gereformecrde belydenis van die gemeenskap van die gelowiges.

Dic dekades '60 en '70 het 'n groter openheid bevorder, deels ten gevolge van die uitwendige maar in ewe groot mate ook deur inwendige omstandighede. Soos so dikwels in die geskiedenis van alle volke het die kuns, uiteraard veral dic woordkuns, ook baanbrekend die nuwe atmosfeer verwoord en verklank. En soos so dik wels ook gebeur het, het die irrasioncle waagmoed en stuwende emosic (allerindividucelste ekspressic van dic allerindividueclste emosie!) so ver vooruit beweeg dat dit kontak met en die ver- 
troue van baie Afrikaners verloor het omdat dit op politieke, sosiale en etniese gebied die grense van verantwoordelikheid skyn. baar of in werklikheid oortree het.

Die natuurlike groei van die volk het op hierdie stadium ook veel groter horisontale en vertikale diversiteit laat uitbot in die vorm onder andere van nuwe beroepe, ambagte en nerings, groter klasseverskille met meer skakeringe van lewensvorme en -wyses. Differensiasie van politieke beskouinge en godsdienstige geloofsoortuigings, van ideologie en lewensbeskouings, van sedelikheid en gedragsnorme het gestalte gekry. Bram Fischer word ontmasker as leier van die kommunistiese aksie in die land. Afrikaners vind 'n politieke tuiste in die Progressiewe Party. Nakomelinge van Christen-Afrikaners omhels die Islam, en Yoga-beoefening word 'n mode. Die kinders van konserwatiewe boere word hardgebakte, bydertydse sakelui wat die wêreld bereis en internasionale kontakte aanknoop.

Die belangrikheid van hierdie tydvak as kulturele waterskeiding blyk veral uit die openbaring van die generasiegaping. 'n Geslag wat na die Tweede Wêreldoorlog gebore is en grootgeword het, bereik die eerste fase van volwassenheid. Hulle ken nòg armoede nog politieke onderdanigheid. Hulle is geestelik kinders van die nuwe "globale" wêreld. Haarstyl, voorkoms en kleredrag beklemtoon die oorgangspanning. Wat vir hulle slegs mode is, is vir 'n groot deel van die ouer generasie heiligskennis en simptome van denasionalisering, simbole en uitwendige manifestasie van onaanvaarbare vreemde en onvolkse waardes: lang hare vir mans, broekpakke vir vroue, Mar-snorre, stoofpypbroeke, denims en klinknaelklere. Hulle laat hulle baard groei maar sonder enige assosiasie met die motiewe van die simboliese ossewatrek van 1938 .

Alle vrees ten spyt is hulle nog Afrikaners soos ek in die dertigerjare as student - laat ek kwalifiseer: as rebelse Afrikanerstudent - „oxford bags" gedra het en my vader noupypbroeke! 


\section{LITERATUUR}

B.IRTH, Fredrik (red.). 1969. lithnic groups and boundaries. Londion.

B.ISTI.N. Idolf. 1860. Der Mensch in der Geschichte. Leipzig.

COI:TZLE., J.II. 1969. Die Ifrikaner. die Nasionale Party. Calvinisme en Engelssprekendes. Dic Volksblad, 30 April.

COETZLE, J.H. 1976. Kesensie van Looking at the Afrikaner today. Woord en Daad, Julie.

COE.TZEE, J.H. 1977 (?). Formative factors in the origins and growth of Afrikaner ethnicity. (In Du Toit, Brian, red. lithnicity in Africa. Ter perse).

ERASMUS, P.F. De persoonlikheid van die Bantoe aan die hand van die analitiese sielkunds van Szondi. PU vir CHO. Ongepubliseerde proefskrif.

FOR'TES, M. \& K.E. Evans-Pritchard (red.). 1950. African political systems. Oxford.

HERDER, Joh. Gottfried. 1785-1791. Ideen zur Philosophie der Menschheit. Riga en Leipzig.

KRUGF.R, Dreyer. 1976. Die Afrikaner: Quo vadis. Deurbraak, September.

MÜHLMANN, Wilhelm. 1938. Methodik der Völkerkunde. Stuttgart.

MÜHLMANN, Wilhelm. 1964. Rassen, Ethnien, Kulturen. Berlyn.

SER FONTEIN, J.H.P. 1970. Die verkrampte aanslag. Kaapstad.

SHIROKOGOROFF, S.M. 1935. The psychomental complex of the Tungus. London.

SZONDI, L. 1952. Experimental diagnostics of drives. New York.

SZONDI, L. 1959. Schicksal psychology. New York.

VAN DEN HEFVER, C.M. e.a. 1945. Kultuurgeskiedenis van die Afrikaner, deel I.

VAN DER MERWE, Hendrik W. (red.). 1975. Looking at the Afrikaner today. 